\title{
Platinum-based anticancer drugs encapsulated liposome and polymeric micelle formulation in clinical trials
}

\author{
Zhou Hang ${ }^{1}$, Matthew A. Cooper ${ }^{2}$ and Zyta M. Ziora ${ }^{2^{*}}$
}

*Correspondence: z.ziora@imb.uq.edu.au

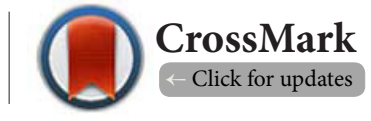

${ }^{1}$ The University of Queensland, School of Chemistry and Molecular Biosciences, St Lucia QLD 4067, Australia.

${ }^{2}$ The University of Queensland, Institute for Molecular Bioscience, St Lucia, QLD 4072, Australia.

\begin{abstract}
Platinum-based anticancer drugs are one of the most widely used drug classes in cancer therapy. Almost half of the chemotherapy regimens used today contains a platinum drug, such as cisplatin or carboplatin. However, the drug resistance and non-specific cytotoxicity ultimately limits broader application of these drugs. Improvement of drug targeting and delivery systems are effective approaches to mitigate these disadvantages. This review focuses on liposome and micelle-based formulations using in the delivery of platinum-based anticancer drugs in clinical trials.
\end{abstract}

Keywords: Anticancer agents, cisplatin, liposome-based formulations, micelle-based formulations

\section{Introduction}

Cancer is one of the most serious and widespread diseases in the modern ages, with predictions that the number of cancer patients will double by 2050 [1], leading to a dramatic growth in demand for more effective cancer therapies. Today, platinumbased chemotherapy is a backbone of cancer treatment. Approximately $50 \%$ cancer patients who receive chemotherapeutic treatment are given using platinum-based anticancer drugs [2]. Platinum-based anticancer drugs can be applied in variety of cancers such as non-small and small cell breast, colorectal, lung, esophageal, gastric, cervical, ovarian and testicular cancers and melanoma, myelomas and lymphomas $[3,4]$. The most widely used platinum-based drug in cancer therapy is cisplatin, which was first described by Peyrone in 1845 [5], and approved by the US Food and Drug Administration (FDA) in 1978. The anti-neoplastic activity of cisplatin was reported by Barnett Rosenberg in 1960s, from which time it began being used in cancer therapy [6]. The use of cisplatin improves survival rate of treated cancer patients. For example, in testicular cancer therapy, the cure rate increases approximately tenfold with cisplatin compare to untreated groups [7]. The main mechanism of action of platinum-based chemotherapeutics is interaction with DNA and induction of apoptosis of tumor cells [8].

Although the platinum-based anticancer drugs are very potent, there are several significant shortcomings. These include their low solubility in water, unsuitability for oral administration, and short half-life in the body $[\mathbf{9}, \mathbf{1 0}]$. However, the major disadvantage is their poor specificity, which is associated with severe side effects [11]. During the treatment there are often major systemic toxicities, such as neurotoxicity, nephrotoxicity and ototoxicity, which limit the administered dose of platinum drugs [12-15]. In addition, the intrinsic and acquired drug resistance is generated when tumors interact with sub-lethal doses of platinum-based drugs $[4,16]$. These two drawbacks restrict the efficacy of drugs. In order to deal with these issues, two major strategies could be implemented. One is to continue conducting research on developing better analogs of platinum drugs. Another is to apply bespoke drug delivery system to improve potency, while reduce side effects of currently used platinum drugs [17].

\section{Review}

\section{Platinum-based anticancer drugs}

Since cisplatin was approved in 1978, thousands of platinumbased drugs have been developed with reduced toxicity and improved efficacy $[18,19]$. Among these products, 25 platinum drugs are in clinical trials, while several others have been already approved for use in humans, including carboplatin and oxaliplatin approved globally, as well as, nedaplatin approved in Japan, lobaplatin approved in China and heptaplatin (SK12053R) approved in Korea (Table 1) [20,21].

In general, platinum-based drugs have two different types of ligands attached to a central platinum cation (Figure 1). One type is amine or amine carrier ligands that strongly bind to the 
Hang et al. Biochemical Compounds 2016,

http://www.hoajonline.com/journals/pdf/2052-9341-4-2.pdf

Table 1. Six representative platinum-base anticancer drugs in the current clinical trials.

\begin{tabular}{|c|c|c|c|c|c|c|}
\hline & Cisplatin & Carboplatin & Oxaliplatin & Nedaplatin & Lobaplatin & Heptaplatin \\
\hline Structure & 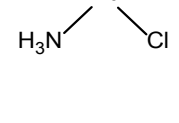 & & & & & \\
\hline $\begin{array}{l}\text { Year of } \\
\text { approval } \\
\text { and Market } \\
\text { status }\end{array}$ & $\begin{array}{l}1979 \\
\text { Worldwide }\end{array}$ & $\begin{array}{l}1989 \\
\text { Worldwide }\end{array}$ & $\begin{array}{l}2002 \\
\text { Worldwide }\end{array}$ & $\begin{array}{l}1996 \\
\text { Japan }\end{array}$ & $\begin{array}{l}2004 \\
\text { China }\end{array}$ & $\begin{array}{l}2005 \\
\text { Korea }\end{array}$ \\
\hline $\begin{array}{l}\text { Clinical } \\
\text { use }\end{array}$ & $\begin{array}{l}\text { Lung, } \\
\text { ovarian, } \\
\text { testicular, } \\
\text { breast and } \\
\text { brain cancer, } \\
\text { sarcomas, } \\
\text { lymphomas }\end{array}$ & $\begin{array}{l}\text { Advanced ovarian } \\
\text { carcinoma, head } \\
\text { and neck, and } \\
\text { lung cancer }\end{array}$ & $\begin{array}{l}\text { Metastatic } \\
\text { colorectal cancer, } \\
\text { advanced gastric } \\
\text { and ovarian cancer }\end{array}$ & $\begin{array}{l}\text { Small and non- } \\
\text { small cell lung } \\
\text { cancer, head } \\
\text { and neck cancer, } \\
\text { esophageal, bladder, } \\
\text { ovary and cervix } \\
\text { cancer }\end{array}$ & $\begin{array}{l}\text { Breast, testicular, small } \\
\text { cell lung, gastric and } \\
\text { ovarian cancer, chronic } \\
\text { myeloid leukemia }\end{array}$ & Gastric cancer \\
\hline
\end{tabular}

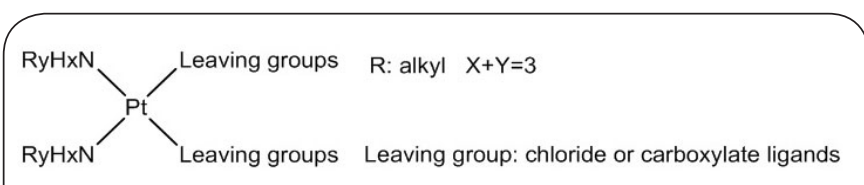

Figure 1. Schematic structure of typical platinum (II) drugs.

platinum ion. The activity of platinum drugs which have at least one ligand based on nitrogen is decreasing in following the order with $\mathrm{NH}_{X} \mathrm{R}_{\mathrm{Y}}(\mathrm{R}$ is alkyl, $\mathrm{X}+\mathrm{Y}=3): \mathrm{NH}_{3}>\mathrm{NH}_{2} \mathrm{R}>\mathrm{NHR}_{2}>\mathrm{NR}_{3}$. Another type of ligands is labile chloride or carboxylate ligands, also termed leaving groups that allow the platinum ion to form bonds with DNA bases. The stronger ligands lead to less active platinum drugs, whereas the high toxicity of platinum complex is caused by highly unstable ligands such as $\mathrm{NO}_{3}{ }^{-}[\mathbf{2 2}, \mathbf{2 3}]$.

Although the mechanism of action of platinum agents in cancer is still not completely understood, there are three major steps associated with these drugs action: i) cellular uptake of drugs; ii) drug interaction with DNA; and interference with transcription and replication mechanisms iii) the Pt-DNA lesion which induce the death of cell by activating signal transduction pathways $[21,24]$.

The efficiency of uptake is directly associated with the efficacy of platinum drugs. Initially, passive diffusion was suggested as main pathway of platinum drugs transport [21,25]. Recently, studies revealed that various cellular transporters play a significant role in the uptake of platinum drugs [21]. For example, the copper transporter CTR1 and CTR2 are considered as a major gateway for platinum drugs access into the cell; however, the exact mechanism remains ambiguous [26-28]. In ovarian cancer cell lines, acquired cisplatin resistance was shown to increase when the cell decreased the expression of CTR1 [29]. Furthermore, the organic cation transporters (OCTs) have been proven to facilitate the transport of platinum drugs, such as oxaliplatin, into cells [30]. Therefore, passive, active and facilitated transport mechanisms all have effects on the uptake of platinum complexes [21].

Once platinum complexes have entered into the cell, activation (via an aquation process) occurs (Figure 2) [21,24]. The leaving group is replaced by water molecules to form monoand di- aqua platinum complexes, which are the most active forms of the drug. Hydroxo-bridged platinum(II) multimers the least active forms are generated (Figure 2) [31].

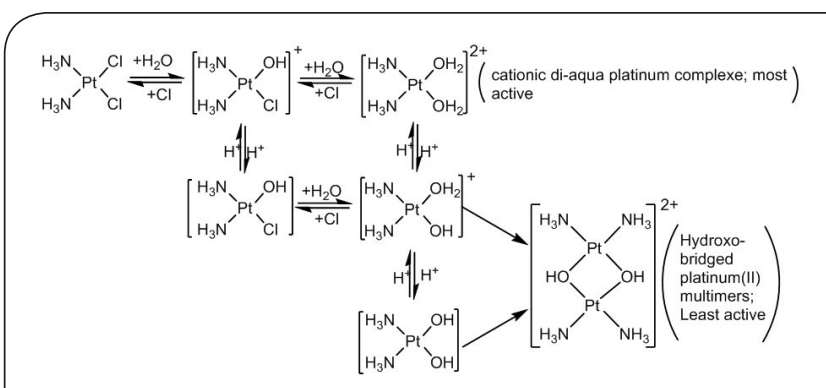

Figure 2. Intercellular aquation of Cisplatin.

For example, after cisplatin enters into a cell, lower intracellular chloride concentrations (3-20 mM), in comparison to extracellular chloride concentration (100 mM), favours formation of the cationic aqua of platinum complexes [24]. This process has two significant implications: i) activated drugs are entrapped in the cell; and ii) the activated/aquated platinum complexes have the ability to bind to intracellular targets (DNA, RNA and proteins) [32]. The toxicity of platinum-based drugs is associated with the rate of exchange of water molecules with leaving groups. More severe systemic toxicity is caused by compounds that undergo more rapid aquation in the blood. Although toxicity could be minimized by the lower aquation, the activity of anticancer would also be reduced [33].

The cytotoxicity of platinum-based drugs is induced by the activated/aquated platinum species binding to intracel- 
lular targets: predominantly DNA [34]. The activated/aquated platinum species are able to react with purine bases of DNA at nucleophilic centers. The N7 position of guanosine and adenosine residues is the most frequent binding site [24]. This binding causes a change of DNA structure, thus, the DNA duplex then unwinds, bends and destabilizes [35]. Two types of cross-links are formed in Pt-DNA adducts: intrastrand cross-links (more common), and interstrand cross-links as the platinum center has two liable sites that can react with the same, or two different, strands of DNA, respectively $[24,36]$. The effect of intrastrand cross-links is stronger than that of interstrand cross-links [37]. When DNA from patients who were treated with cisplatin was analyzed, interstrand crosslinks accounted only for only a few percent of all Pt-DNA adducts $[21,38]$.

After cellular machinery recognizes DNA adducts, three concurrent potential pathways can be induced: i) repairing, ii) bypassing affected DNA fragment and iii) apoptosis. It is believed the inhibition of transcription is the most likely to induce cellapoptosis in the presence of platinum drugs. The program of cell apoptosis is evoked if the DNA lesion cannot be repaired by cells [24]. However, the complete mechanism is still not clear as novel facts related to this mechanism are continuously discovered. For example, it was demonstrated that the death receptor $\mathrm{CD} 95$ was redistributed into membrane lipid rafts of human colon cell lines upon cisplatin action, and it caused sensitization to CD9-mediated apoptosis [39].

Although platinum-based dugs can induce cancer cell death, there have been only two new platinum-based drugs entering clinical trials in last ten years [4].

\section{Drug delivery system for platinum-based anticancer drugs}

Targeted therapy has the potential to reduce the damage of normal cells and retard the evolution of drug resistance $[17,40]$. Several tumor targeting delivery systems have been investigated $[\mathbf{4 0 , 4 1 ]}$.

Drug delivery systems can be separated into two categories: active and passive [17]. Active drug delivery systems exploit fact that there are the differences between tumors and normal tissues, and the interactions between anticancer drugs and the tumor cells containing the specific quantity or functionality of biomolecular entities [17]. In an active drug targeting and delivery system, the targeting moiety can be bound to the pharmacophore, and the specific binding affinity of this moiety can guide pharmacophore towards the targeting tumor tissues via transporter-based, antigen-based or receptor-based conjugates [42]. In active drug delivery systems, estrogens, carbohydrates, bisphosphonates, peptides and proteins, and cucubiturils are usually used as targeting ligands for platinum-based anticancer drugs.

Passive drug delivery systems are usually based on the enhanced permeability and retention (EPR) effect in neoplastic tissues [43]. Since the vasculature in tumor tissue is often twisted and disorganized, there are more fenestrations and open junctions (size $200 \mathrm{~nm} \sim 1.2 \mu \mathrm{m}$ ) compared with vasculature in normal tissues [44]. Most nanoparticles (with the dimensions up to a few hundred nanometers) can cross fenestrations and reach tumor tissue. Furthermore, excess fluid from the solid tumor tissue is hardly to be removed as the functional lymphatic network is deficient. Therefore, the solid tumor tissues, in contrast to healthy tissue, can accumulate the large nanoparticles (100-300 nm) and retain them for a relatively long time [44]. Most types of solid tumor have EPR effects, and therefore tumor tissue concentrations can be enhanced 10 30-fold compared with that in other tissues. Passive drug delivery in tumor tissues and longer drug retention are key benefits of the EPR effect. In passive drug delivery, the carrier usually contains donor groups which could coordinate with the platinum moiety for platinum antitumor drugs [17]. Nanoparticles, such as liposomes and polymeric micelles, are suitable carriers for use in passive drug delivery systems that exploit the EPR effect $[46,47]$.

\section{Liposomes}

Liposomes were recognized as potential drug delivery systems in 1965 [48] (Figure 3) are spherical vesicles, with aqueous inner core surrounded by concentric bilayers of phospholipids [49]. Liposomes are biocompatible, and they have abilities to loading hydrophilic or hydrophobic drugs in their internal water compartment and membrane, respectively. Liposomal formulations can be easily modified to match the pharmacokinetic profile of encapsulated drugs, with properties as size and charge easily altered. For targeted delivery of anticancer agents, liposomes can be designed to accumulate in the cancer tissue. For example, Doxil is the first approved liposomal antitumor drug by the US Food and

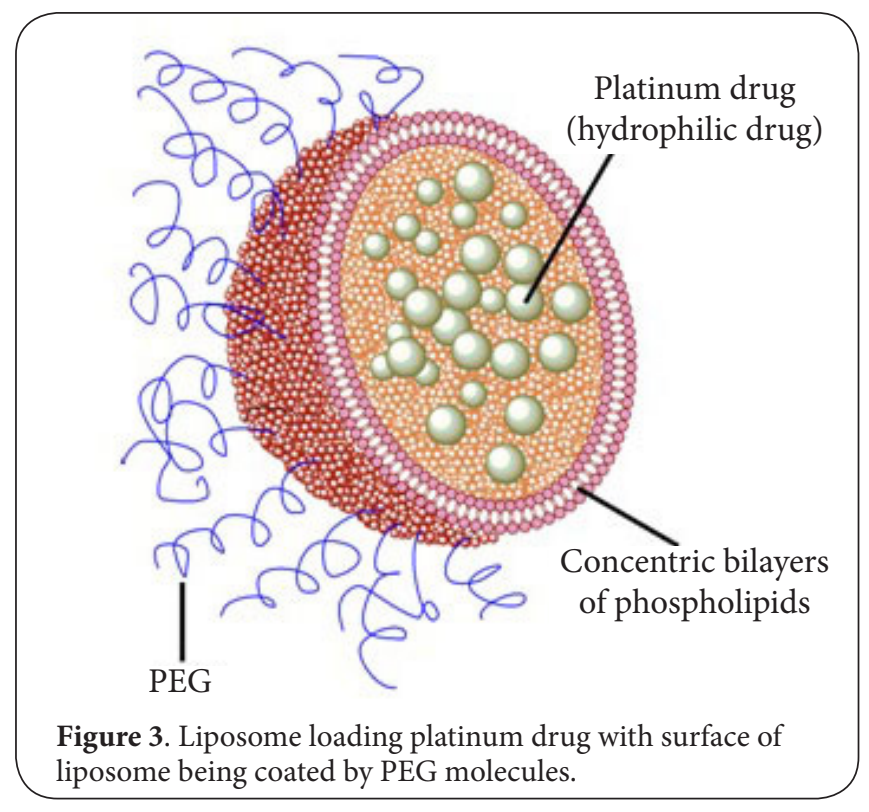


Hang et al. Biochemical Compounds 2016,

Drug Administration, FDA. Doxil is a doxorubicin encapsulated by a PEGylated liposomal formulation. Importantly, the EPR effect was first observed and proved in human, and through the passive drug delivery system, Doxil was accumulated in tumor tissues [50]. Then, platinum-based anticancer drugs encapsulated by liposomes have been investigated. So far, there are six types of liposomal platinum anticancer drugs in clinical trials (Table 2).

\section{Lipoplatin}

Lipoplatin ${ }^{\mathrm{TM}}$ is a liposomal formulation built from methoxy polyethylene glycol-distearoyl phosphatidyl-thanolamine, soy phosphatidylcholine, cholesterol and dipalmitoyl phosphatidyl glycerol (DPPG) containing cisplatin [51]. The ratio between cisplatin and total lipid content is approximately $1: 10$, and the average diameter of Lipoplatin vesicles is $110 \mathrm{~nm}$ [52]. In order to keep liposomes more stable in body fluids and avoid immune responses against them, polyethylene glycol (PEG) was introduced onto the phospholipid bilayer surface. The uptake, accumulation and retention of Lipoplatin in tumor tissues are improved in comparison to the parent drug [53]. Upon encapsulation in PEGylated liposomes, the solubility of cisplatin is improved threefold and the circulation time prolonged almost 20-fold [17].

In pre-clinical studies in mice and rats nephrotoxicity and side effects were reduced with Lipoplatin compared to free cisplatin, with concomitant improvement in anticancer activity observed in prostate LNCaP human tumor xenograft and breast MCF-7 models [54,55]. Moreover, study on healthy dogs showed that the drug dose that could be safely injected was above $150 \mathrm{mg} / \mathrm{m}^{2}$, which was twice the level tolerated for free cisplatin [56]. Pre-clinical studies of Lipoplatin showed that, the ability of antitumor was stronger against non-small cell lung cancer (NSCLC), and for normal cells, the Lipoplatin showed a much lower toxicity [57]. Some clinical trials of Lipoplatin have entered Phase III. Several clinical studies have shown that Lipoplatin could not only improve the efficacy of cisplatin compare to pure cisplatin, but also reduce systemic toxicities such as myelotoxicity, ototoxicity, peripheral neuropathy and renal toxicity [58]. The accumulation of platinum drugs in solid tumors was up to 200 -fold higher than that in adjacent normal tissues [51]. When Lipoplatin was used with other anticancer drugs such as paclitaxel or gemcitabine, the efficacy of treatment was similar or higher than that of cisplatin and the systemic toxicities were substantially reduced $[52,59]$. For example, one clinical study showed that twice as many patients survived when using Lipoplatin combined with paclitaxel compared with those using cisplatin combined with paclitaxel [60]. Lipoplatin also shows positive results in some Phase II and III trials for head and neck cancer, breast cancer, gastric cancer, and pancreatic cancer [51].

\section{SPI-077}

SPI-077 is a long-circulating and sterically stabilized cisplatin encapsulated by liposomes. SPI-077 is composed of all neutral lipids (the molar ratio of hydrogenated soy phosphatidylcholine, cholesterol and DSPE-PEG2000 is $51: 44: 5$ ), and the cisplatin to total lipid ration is $1: 70$, and the size is $110 \mathrm{~nm}$ [61]. SPI-077 has a long blood circulation time. It is estimated that the half-life of SPI-077 is around 16 hours in mice, while half-life of cisplatin is about 0.24 hours. Furthermore the plasma concentration-time curve (AUC) was 60 times greater with SPI-077compared to cisplatin, the amount of platinum accumulated in kidneys 4-fold lower, while the platinum AUC in tumor was 28 times higher [62]. In C26 and Lewis lung tumor xenograft models, the toleration and effectiveness were also enhanced by using SPI-077 compared with free cisplatin [62]. Despite superior pharmacokinetic profile of SPI-077 in preclinical experiments, enhancement of drug efficacy over cisplatin was not observed in several pre-clinical experiments including A-375 melanoma, M-109 lung carcinoma and J-6456 lymphoma in mouse [63]. Moreover, it has been shown that liposomes of SPI-077 were able to release $10 \%$ of cisplatin. The cytotoxic activity of SPI-077 was also reduced in vitro compared with cisplatin [64]. This poor performance might be related to extremely slow release of drug from liposomes

Table 2. Liposomal formulated platinum-based drugs in clinical trials.

\begin{tabular}{lllllll}
\hline $\begin{array}{l}\text { Liposomal } \\
\text { formulation }\end{array}$ & $\begin{array}{l}\text { Platinum-based } \\
\text { drugs }\end{array}$ & Liposome & Status & $\begin{array}{l}\text { Drug-lipid } \\
\text { weight ratio }\end{array}$ & $\begin{array}{l}\text { MTD } \\
\left(\mathbf{m g} / \mathbf{m}^{2}\right)\end{array}$ & References \\
\hline Lipoplatin & Cisplatin & HSPC/DPPG/DSPE-PEG2000 & Phase II/III & $1: 10$ & 300 & $51 \sim 60$ \\
SPI-077 & Cisplatin & HSPC/cholesterol/DSPE-PEG2000 & Phase II & $1: 70$ & 420 & $61 \sim 69$ \\
LiPlaCis & Cisplatin & DSPC/DSPG/DSPE-PEG2000 & Phase I & -- & -- & 70 \\
Lipoxal & Oxaliplatin & HSPC/DPPG/DSPE-PEG2000 & Phase I & -- & 300 & 71,72 \\
Aroplatin & NDDP & DMPC/DMPG & Phase II & $1: 15$ & 312.5 & $73 \sim 79$ \\
MBP-426 & Oxaliplatin & TF-PEG-liposomes & Phase I/II & -- & 226 & $80 \sim 82$ \\
\hline
\end{tabular}

MTD: Maximum tolerated dose; HSPC: Hydrogenated soy phosphatidylcholine; DPPG: 1,2-dipalmitoyl-sn-glycero-3phospho-(1'-rac-glycerol). DSPE-PEG2000: 1,2-distearoyl-sn-glycero-3-phosphoethanolamine-N-\{methoxy(polyethylene glycol)-2000\}. DSPC: 1,2-distearoyl-sn-glycero-3-phosphocholine. DSPG: 1,2-distearoyl-sn-glycero-3-phospho-(1'-racglycerol). DMPC: 1,2-dimyristoyl-sn-glycero-3-phosphocholine. DMPG: 1,2-dimyristoyl-sn-glycero-3-phospho-(1'-racglycerol). PEG: poly(ethylene glycol). NDDP: cis-bis-neodecanoato-trans-R,R-1,2-diaminocyclohexane platinum (II) 
at the cancer locus [64]. In a Phase I experiment, patients were administrated with a $420 \mathrm{mg} / \mathrm{m}^{2}$ dose of SPI-077 [65], and long circulation time of drug was observed. SPI-077 was tolerated in human bodies in a dose range from 40 to $420 \mathrm{mg} / \mathrm{m}^{2}$, and patients suffered only from mild side effects: muscle weakness, mild anemia and mild gastrointestinal toxicity. However, in several Phase II trials, most of patients who had advanced non-small-cell lung cancer, platinum-sensitive recurrence of ovarian cancer or head and neck cancer did not generate a strong response to SPI-077 [66-68]. Some preclinical studies and Phase II studies showed extremely slow release of cisplatin from SPI-077, leading to the low therapeutic efficacy. SPI-077was subsequently removed from clinical studies [69].

\section{LiPlaCis}

LiPlaCis is a cisplatin drug encapsulated by liposomal formulation which is composed of 1,2-disteroyl-sn-glycero-3-phosphocholine, 1,2-disteroyl-sn-glycero-3-\{phosphor-rac-(1-glycerol)\} (sodium salt) and 1,2-disteroyl-sn-glycero-3-phosphoethanolamine- $\mathrm{N}$-\{methoxy(polyethylene glycol)-2000\} (ammonium salt). Disodium hydrogen phosphate, sodium chloride, and sucrose are added as stabilizers. As with SPI-077, it is believed that it is difficult for cisplatin to cross a lipid membrane. It has been demonstrated that liposomes of LiPLaCis are degraded by secretory phospholipase $A_{2}$ at tumor site to release cisplatin [70]. Unfortunately, severe renal toxicity and an acute infusion reaction were observed in patients in Phase I study. Thus LiPlaCis clinical studies were halted [49].

\section{Lipoxal}

Lipoxal is liposomal formulations of oxaliplatin [71]. In a Phase I study, a dose range from $100 \mathrm{mg} / \mathrm{m}^{2}$ to $250 \mathrm{mg} / \mathrm{m}^{2}$ did not induce any obvious side effects. At doses of $300 \mathrm{mg} / \mathrm{m}^{2} \sim 350$ $\mathrm{mg} / \mathrm{m}^{2}$, nausea, mild myelotoxicity and grade 2-3 peripheral neuropathy were observed [72]. Oxaliplatin minimized many side effects such as gastrointestinal tract toxicity and myelotoxicity while maintaining anticancer potency. The cellular uptake of oxaliplatin remarkably improved when administered as Lipoxal in comparison to pure oxaliplatin [71]. Further study on Lipoxal can be expected in near future.

\section{Aroplatin}

Aroplatin (L-NDDP) is a liposome encapsulating a cis-bisneodecanoato-trans-R, R-1,2-diaminocyclohexane platinum II, (NDDP an oxaliplatin derivative). This is first liposomal formulation loading new cisplatin analog in the clinic [49]. Multi-lamellar liposomes were formed from 1,2-dimyristoylsn-glycero-3-phospho-(1'-racglycerol) (DMPG) and 1,2-dimyristoyl-sn-glycero-3-phosphocholine (DMPC) lipids in acidified saline solution, and then NDDP were encapsulated by these liposomes to form Aroplatin [73].

In pre-clinical study, there were significant differences in the biodistribution between Aroplatin and NDDP. Major organs such as lymph nodes and liver accumulated platinum after patient treatment with Aroplatin [74,75]. In toxicity test, Aroplatin did not show the nephrotoxicity, but myelosuppression was observed. Diffuse hemorrhagic syndrome was also caused by Aroplatin in canine models [76]. However, stronger anticancer activities were observed for liver and spleen metastases in mice when treated with Aroplatin [77]. Importantly, Aroplatin did not share cross-resistance with cisplatin [17]. In a Phase I study, patients who received an intravenous administration every 4 weeks showed that 312.5 $\mathrm{mg} / \mathrm{m}^{2}$ was the maximum tolerated dose (MTD) of Aroplatin. The myelosuppression occurred when the dose of Aroplatin was close to MTD $[\mathbf{7 8 , 7 9 ]}$. In Phase II study, Aroplatin was tested in refractory metastatic colorectal cancer to produce the partial response $(5.6 \%)$, the stable disease $(16.7 \%)$ and the development of disease progression (77.8\%) in patients. In general, the response was modest. Aroplatin was also well tolerated, nearly half patients were able to receive Aroplatin in high dose $\left(375 \mathrm{mg} / \mathrm{m}^{2}\right)$ [79]. Although Aroplatin demonstrated promising efficacy and safety profile, there is no report of any ongoing Phase III study.

\section{MBP-426}

MBP-426 is a transferrin (TF)-conjugated N-glutaryl phosphatidylethanolamine liposomal formulation encapsulating oxaliplatin. The TF receptor is overexpressed in several types of cancers [17]. The retention time of oxaliplatin was prolonged in tumor tissues (Colin 26 tumor) while reduced in blood, when tested in mice model. MBP-426 was more effective to suppress the growth of tumor cells compared with pure oxalplatin [80]. In Phase I study, the dose of $226 \mathrm{mg} / \mathrm{m}^{2} \mathrm{MBP}$ 426 was safe when injected every three weeks. Dose-limiting toxicities were thromboccytopennia at the dose of $400 \mathrm{mg} /$ $\mathrm{m}^{2}$ [81]. Thus, $226 \mathrm{mg} / \mathrm{m}^{2}$ of MBP-426 is recommended for the Phase II study, which is ongoing $[21,82]$.

\section{Polymeric micelles}

Polymeric micelles (Figure 4) are formed by amphiphilic block

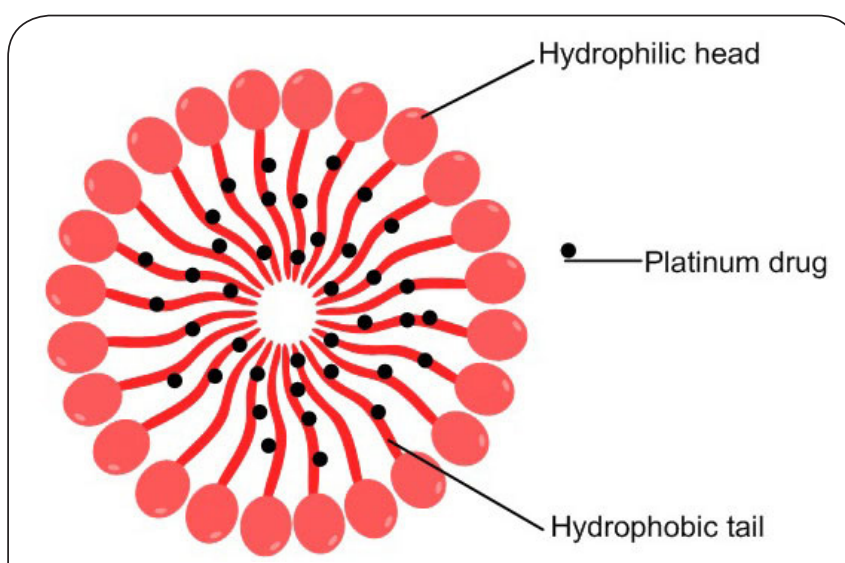

Figure 4. The structure of polymeric micelle loading platinum drugs. 
copolymers [83], and including inner core (hydrophobic) and outer shellsegments (hydrophilic) [84]. The loading, stability, and releasing of drugs are associated with inner core while the behavior of pharmacokinetics is controlled by the outer shell. The anticancer drugs such as cisplatin could be incorporated into the inner core of polymeric micelles [17]. Incorporation of the drug into micelles increases its stability. Nowadays, there are two types of polymeric micelles containing platinumbased anticancer complexes in clinical trials: NC-6004 and NC-4016 (Table 3).

\section{NC-6004}

NC-6004 (Figure 5) is a cisplatin encapsulated by polymeric micelles (30 nm), composed of block copolymer containing PEG (outer shell) and poly(glutamic acid) (pGlu) (inner core) coordinated with cis-diammineplatinum moieties [85].

In pre-clinical study, the blood retention profile of NC-6004 was longer than free cisplatin, and the tumor AUC of NC-6004 was 3.6 times higher than that of cisplatin [86]. There was no obvious differences in suppression of human gastric cancer (cell line MKN-45) in a murine model when NC-6004 $(5 \mathrm{mg} / \mathrm{kg}$ of (DDP) was compared with cisplatin. Pre-clinical studies showed that neurotoxicity was minimized by injecting NC6004 compared with cisplatin [87]. In a Phase I clinical study of NC-6004, the dosage from $10 \mathrm{mg} / \mathrm{m}^{2}$ to $120 \mathrm{mg} / \mathrm{m}^{2}$ was injected one time every three weeks. When the dose was up to $120 \mathrm{mg} / \mathrm{m}^{2}$, nephrotoxicity was not observed. Therefore, $120 \mathrm{mg} / \mathrm{m}^{2}$ was recommend as the maximal tolerated dose for further clinical studies. Unfortunately, NC-6004 induced more frequently hypersensitivity reaction in comparison to free drug [88]. Nanocarrier, a biotechnology company, has recently inititated aPhase II/ III study on NC-6004 [89].

\section{NC-4016}

NC-4016 (Figure 6) is a polymeric micelle loading DACHPt. The structure of NC-4016 is similar to that of NC-6004, in that it is composed of outer shell, which is comprised by hydrophilic PEG chain, and apGlu inner core that coordinates dichloro-1,2-diaminocyclohexane-platinum (II) (DACHPt, an active oxaliplatin element) [90]. Nanocarrier has begun conducting a Phase I clinical study in US [89].

In distilled water, DACHPt was not released from NC-4016. However, it could be released in media including chloride ions, and NC-4016 was more stable in phosphate buffered saline than NC-6004. Moreover, compared with oxaliplatin, the cytotoxicity of NC-4016 was lower, a longer blood circulation and higher relative tumor targeting than pure oxaliplatin. Furthermore, NC-4016 has potent anticancer activity against both primary solid and metastatic tumors [84]. In pre-clinical studies, NC-4016 inhibited tumor growth in an orthotopic

Table 3. Polymeric micelles containing platinum-based drugs in clinical trials.

\begin{tabular}{llllll}
\hline $\begin{array}{l}\text { Micelle } \\
\text { formulation }\end{array}$ & $\begin{array}{l}\text { Platinum } \\
\text { based drugs }\end{array}$ & Micelles & Status & $\begin{array}{l}\text { MTD } \\
\left(\mathbf{m g} / \mathbf{m}^{2}\right)\end{array}$ & References \\
\hline NC-6004 & cisplatin & $\begin{array}{l}\text { Poly(ethyleneglycol)- } \beta \text { - } \\
\text { poly(glutamic acid) }\end{array}$ & Phase I/II/III & 120 & $85 \sim 89$ \\
NC-4016 & DACHPt & $\begin{array}{l}\text { Poly(ethyleneglycol)- } \beta \text { - } \\
\text { poly(glutamic acid) }\end{array}$ & Phase I & $84,89 \sim 92$ \\
\hline
\end{tabular}

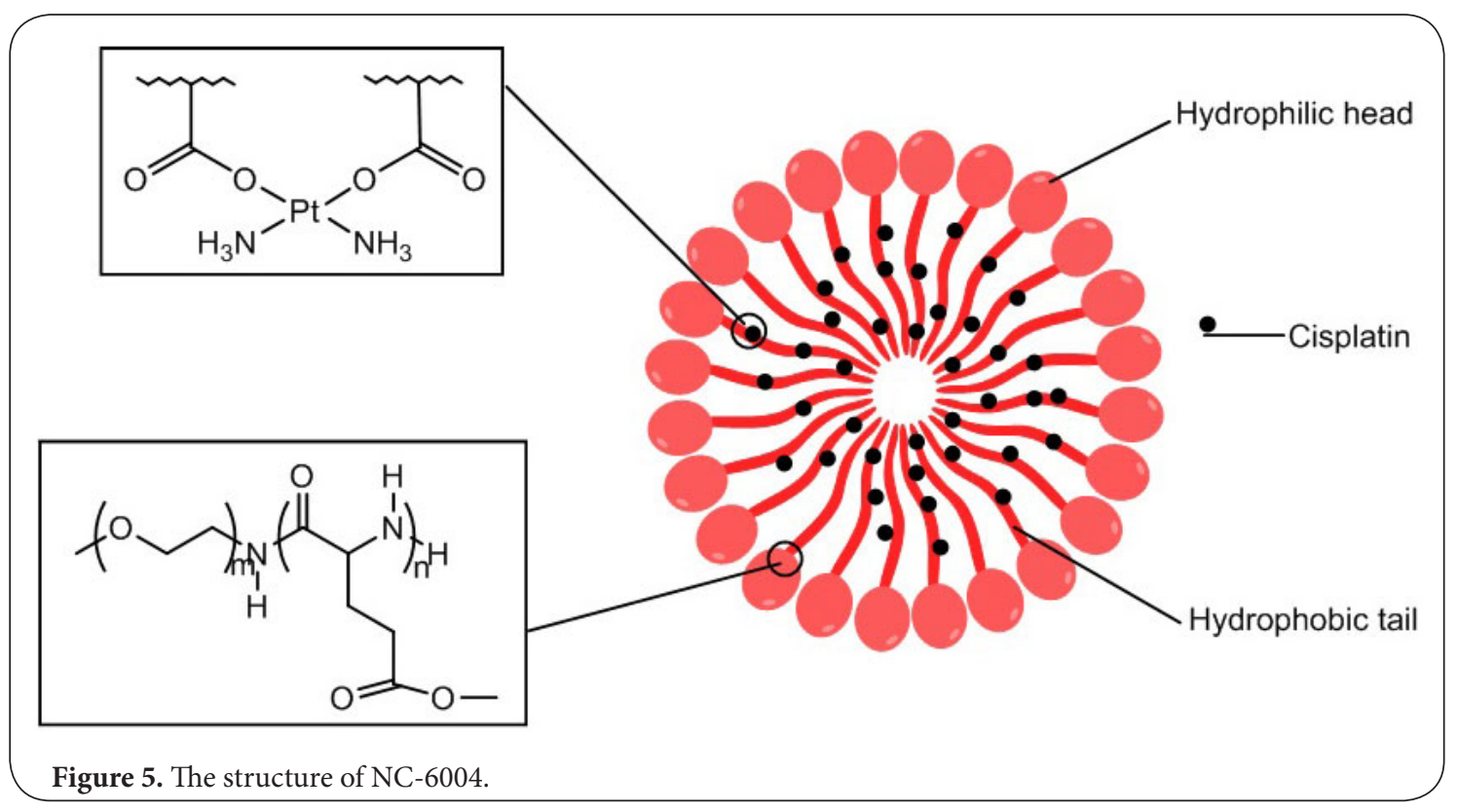




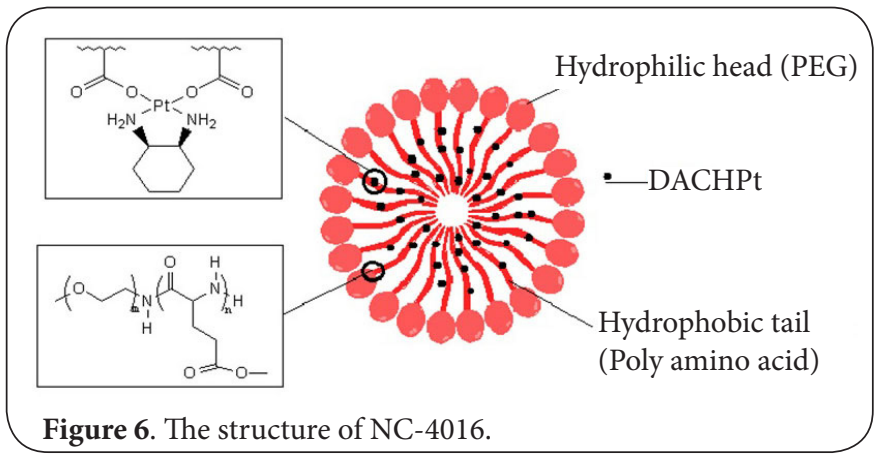

cirrhous gastric cancer and metastatic lymph nodes [91]. Moreover, in a mouse model with human carcinoma cell line KB, NC-4016 showed superior antitumor ability than free Oxaliplatin. Acute cold hypersensitivity, which is frequently occurred by using Oxaliplatin, was not observed in rats that received NC-4016 [92].

\section{Remarks and perspective}

There is no therapeutic regime that can totally cure cancer patients without any side effect, as anticancer drugs can not discriminate between healthy and tumor cells. Besides this lack of specificity, anticancer agents also suffer from diminishing efficacy. Cancer cells can develop mechanisms that can avoid apoptosis caused by cisplatin interactions with DNA. Thus, to overcome problem with poor performance of cisplatin, many analogs have been generated, including carboplatin, oxaliplatin, nedaplatin, heptaplatin and lobplatin. However, all of these platinum-based antitumor drugs have their shortcomings. For example, although the toxicity of carboplatin to normal cells is weaker than cisplatin, its anticancer efficacy also decreases.

In order to enhance efficacy of platinum-based drugs and reduce toxicity, more efficient drug targeting and delivery system are being examined. One of the most promising delivery systems includes liposomes-based targeting delivery exploiting the EPR effect. There are six liposomal platinum-based antitumor drugs that entered to the clinical trials. While some of them showed significant potential to reduce the systemic toxicity, avoid resistance and enhance the efficacy of these platinum-based drugs, other demonstrated poor performance. For example, SPI-077 was not able to release enough free platinum drug in certain time to produce desired anticancer effect. On the other hand, LiPlaCis was discontinued from the trials due to its excessive toxicity. Fortunately, liposomal platinum drugs formulations, such as lipoplatin and lipoxal showed very promising efficacy profiles and practical toxicity.

Most current research focuses on liposomes that encapsulate cisplatin, oxaliplatin, carboplatin, nedaplatin, heptapltin or lobaplatin. The liposomal formulation itself can be also modified. In addition, analogously to MBP-426, tumor targeting moieties can be incorporated on the liposomes to further improve selectivity of the delivery system. Liposomes covered by antibodies are becoming attractive choice for tumor targeting delivery systems.

Nanomedicine is one of the most rapidly developing fields in anticancer therapy and polymer-based delivery system for anticancer agents are a rapidly growing area of research. There are two platinum-based anticancer drugs encapsulated in polymeric micelles in the clinical trials (NC-6004 and NC4016). These two polymeric carriers reduce toxicity of platinum drugs compared with free drugs, while their antitumor efficacy was maintained. In the future other platinum-based anticancer drugs such as carboplatin, nedaplatin, heptaplatin or lobaplatin could be encapsulated by polymeric micelles. Further improvement can be also achieved by combination of more than one anticancer agent in liposomes/micelles delivery system. Combination therapies on their own showed very promising outcomes; incorporation into them additional delivery system might further improve anticancer potency and reduce general toxicity of the therapeutics.

\section{Conclusion}

While some of these drugs did not meet expectations, others showed improved potency and reduced adverse effects in human. However, it is expected that further research and development is required to produce formulation that can reach the market. Thus, the formulation of liposomes and polymeric micelles could be modified by incorporation of cancer targeting moieties or modification of physicochemical properties of delivery system (e.g., size, charge). In addition, different platinum-based drugs could be encapsulated by liposomes and polymeric micelles. Finally, combination therapy can be applied. Hopefully, this optimization process can be performed in the near future leading to a better treatment of cancers.

\section{Competing interests}

The authors declare that they have no competing interests.

Authors' contributions

\begin{tabular}{|l|c|c|c|}
\hline Authors' contributions & ZH & MAC & ZMZ \\
\hline Research concept and design & $\checkmark$ & -- & $\checkmark$ \\
\hline Collection and/or assembly of data & $\checkmark$ & -- & $\checkmark$ \\
\hline Data analysis and interpretation & -- & -- & -- \\
\hline Writing the article & $\checkmark$ & -- & $\checkmark$ \\
\hline Critical revision of the article & -- & $\checkmark$ & $\checkmark$ \\
\hline Final approval of article & -- & $\checkmark$ & $\checkmark$ \\
\hline Statistical analysis & -- & -- & -- \\
\hline
\end{tabular}

\section{Publication history}

Editors: Monica Butnariu, Banat's University of Agricultural Sciences and Veterinary Medicine, Romania.

Francesco Trapasso, Magna Graecia University, Italy.

EIC: Mariusz Skwarczynski, University of Queensland, Australia.

Received: 06-Apr-2016 Final Revised: 02-May-2016

Accepted: 05-May-2016 Published: 11-May-2016 
Hang et al. Biochemical Compounds 2016,

\section{References}

1. Ferlay J, I. Soerjomataram, M. Ervik, R. Dikshit, S. Eser, C. Mathers, M. Rebelo, D. Parkin, D. Forman and F. Bray. GLOBOCAN 2012 v1. 0, cancer incidence and mortality worldwide: IARC CancerBase No. 11 [internet]. International Agency for Research on Cancer, Lyon. globocan. iarc. fr (accessed 10 October 2014). 2013.

2. Galanski M, Jakupec MA and Keppler BK. Update of the preclinical situation of anticancer platinum complexes: novel design strategies and innovative analytical approaches. Curr Med Chem. 2005; 12:2075-94. I Article I PubMed

3. Kelland L. The resurgence of platinum-based cancer chemotherapy. Nat Rev Cancer. 2007; 7:573-84. I Article I PubMed

4. Apps MG, Choi EH and Wheate NJ. The state-of-play and future of platinum drugs. Endocr Relat Cancer. 2015; 22:R219-33. | Article | PubMed

5. Kauffman, G.B., R. Pentimalli, S. Doldi and M.D. Hall. Michele Peyrone (1813-1883), Discoverer of Cisplatin. Platinum Metals Review. 2010; 54:250-256. | Article

6. Rosenberg B, VanCamp L, Trosko JE and Mansour VH. Platinum compounds: a new class of potent antitumour agents. Nature. 1969; 222:385-6. I PubMed

7. Einhorn LH. Treatment of testicular cancer: a new and improved model. J Clin Oncol. 1990; 8:1777-81. | Article | PubMed

8. Wong $E$ and Giandomenico CM. Current status of platinum-based antitumor drugs. Chem Rev. 1999; 99:2451-66. | Article I PubMed

9. Vinh NQ, Naka S, Cabral H, Murayama H, Kaida S, Kataoka K, Morikawa S and Tani T. MRI-detectable polymeric micelles incorporating platinum anticancer drugs enhance survival in an advanced hepatocellular carcinoma model. Int J Nanomedicine. 2015; 10:4137-47. | Article | PubMed Abstract | PubMed FullText

10. Gianasi E, Wasil M, Evagorou EG, Keddle A, Wilson G and Duncan R. HPMA copolymer platinates as novel antitumour agents: in vitro properties, pharmacokinetics and antitumour activity in vivo. Eur J Cancer. 1999; 35:994-1002. | Article | PubMed

11. Rabik CA and Dolan ME. Molecular mechanisms of resistance and toxicity associated with platinating agents. Cancer Treat Rev. 2007; 33:923. | Article | PubMed Abstract | PubMed FullText

12. Argyriou AA, Polychronopoulos P, Iconomou G, Chroni E and Kalofonos HP. A review on oxaliplatin-induced peripheral nerve damage. Cancer Treat Rev. 2008; 34:368-77. I Article I PubMed

13. McWhinney SR, Goldberg RM and McLeod HL. Platinum neurotoxicity pharmacogenetics. Mol Cancer Ther. 2009; 8:10-6. I Article I PubMed Abstract | PubMed FullText

14. Yao X, Panichpisal K, Kurtzman N and Nugent K. Cisplatin nephrotoxicity: a review. Am J Med Sci. 2007; 334:115-24. I Article I PubMed

15. Ruggiero A, Trombatore G, Triarico S, Arena R, Ferrara P, Scalzone M, Pierri $F$ and Riccardi R. Platinum compounds in children with cancer: toxicity and clinical management. Anticancer Drugs. 2013; 24:1007-19. | Article I PubMed

16. Heffeter $P$, Jungwirth $U$, Jakupec $M$, Hartinger $C$, Galanski M, Elbling L, Micksche M, Keppler B and Berger W. Resistance against novel anticancer metal compounds: differences and similarities. Drug Resist Updat. 2008; 11:1-16. | Article | PubMed

17. Wang $X$ and Guo $Z$. Targeting and delivery of platinum-based anticancer drugs. Chem Soc Rev. 2013; 42:202-24. I Article I PubMed

18. Reedijk J. Platinum anticancer coordination compounds: study of DNA binding inspires new drug design. European Journal of Inorganic Chemistry.2009; 2009:1303-1312. | Article

19. Kaluderovic GN and Paschke R. Anticancer metallotherapeutics in preclinical development. Curr Med Chem. 2011; 18:4738-52. | Article | PubMed

20. Wheate NJ, Walker S, Craig GE and Oun R. The status of platinum anticancer drugs in the clinic and in clinical trials. Dalton Trans. 2010; 39:8113-27. | Article | PubMed

21. Oberoi HS, Nukolova NV, Kabanov AV and Bronich TK. Nanocarriers for delivery of platinum anticancer drugs. Adv Drug Deliv Rev. 2013; 65:1667-85. | Article | PubMed Abstract | PubMed FullText

22. Callari, M., J.R. Aldrich-Wright, P.L. de Souza and M.H. Stenzel. Polymers with platinum drugs and other macromolecular metal complexes for cancer treatment. Progress in Polymer Science. 2014; 39:1614-1643. | Article

23. Dasari S and Tchounwou PB. Cisplatin in cancer therapy: molecular mechanisms of action. Eur J Pharmacol. 2014; 740:364-78. | Article | PubMed Abstract | PubMed FullText

24. Johnstone TC, Park GY and Lippard SJ. Understanding and improving platinum anticancer drugs--phenanthriplatin. Anticancer Res. 2014; 34:471-6. | Article | PubMed Abstract | PubMed FullText

25. Gately DP and Howell SB. Cellular accumulation of the anticancer agent cisplatin: a review. Br J Cancer. 1993; 67:1171-6. | PubMed Abstract | PubMed FullText

26. Howell SB, Safaei R, Larson CA and Sailor MJ. Copper transporters and the cellular pharmacology of the platinum-containing cancer drugs. Mol Pharmacol. 2010; 77:887-94. | Article | PubMed Abstract | PubMed FullText

27. Holzer AK, Manorek GH and Howell SB. Contribution of the major copper influx transporter CTR1 to the cellular accumulation of cisplatin, carboplatin, and oxaliplatin. Mol Pharmacol. 2006; 70:1390-4. I Article I PubMed

28. Ivy KD and Kaplan JH. A re-evaluation of the role of hCTR1, the human high-affinity copper transporter, in platinum-drug entry into human cells. Mol Pharmacol. 2013; 83:1237-46. | Article | PubMed Abstract | PubMed FullText

29. Ishida S, Lee J, Thiele DJ and Herskowitz I. Uptake of the anticancer drug cisplatin mediated by the copper transporter Ctr1 in yeast and mammals. Proc Natl Acad Sci U S A. 2002; 99:14298-302. | Article | PubMed Abstract | PubMed FullText

30. Zhang S, Lovejoy KS, Shima JE, Lagpacan LL, Shu Y, Lapuk A, Chen Y, Komori T, Gray JW, Chen X, Lippard SJ and Giacomini KM. Organic cation transporters are determinants of oxaliplatin cytotoxicity. Cancer Res. 2006; 66:8847-57. | Article | PubMed Abstract | PubMed FullText

31. Pinto AL and Lippard SJ. Binding of the antitumor drug cisdiamminedichloroplatinum(II) (cisplatin) to DNA. Biochim Biophys Acta. 1985; 780:167-80. | PubMed

32. Jung $Y$ and Lippard SJ. Direct cellular responses to platinum-induced DNA damage. Chem Rev. 2007; 107:1387-407. | Article | PubMed

33. van Zutphen $S$ and J. Reedijk. Targeting platinum anti-tumour drugs: Overview of strategies employed to reduce systemic toxicity. Coordination chemistry reviews. 2005; 249:2845-2853. I Article

34. Jamieson ER and Lippard SJ. Structure, Recognition, and Processing of Cisplatin-DNA Adducts. Chem Rev. 1999; 99:2467-98. I Article I PubMed

35. Cohen GL, Bauer WR, Barton JK and Lippard SJ. Binding of cis- and trans-dichlorodiammineplatinum(II) to DNA: evidence for unwinding and shortening of the double helix. Science. 1979; 203:1014-6. | Article | PubMed

36. Takahara PM, Rosenzweig AC, Frederick CA and Lippard SJ. Crystal structure of double-stranded DNA containing the major adduct of the anticancer drug cisplatin. Nature. 1995; 377:649-52. I Article I PubMed

37. Coste F, Malinge JM, Serre L, Shepard W, Roth M, Leng M and Zelwer C. Crystal structure of a double-stranded DNA containing a cisplatin interstrand cross-link at $1.63 \mathrm{~A}$ resolution: hydration at the platinated site. Nucleic Acids Res. 1999; 27:1837-46. | Article | PubMed Abstract | PubMed FullText

38. Fichtinger-Schepman AM, van Oosterom AT, Lohman PH and Berends F. cis-Diamminedichloroplatinum(II)-induced DNA adducts in peripheral leukocytes from seven cancer patients: quantitative immunochemical detection of the adduct induction and removal after a single dose of cis-diamminedichloroplatinum(II). Cancer Res. 1987; 47:3000-4. | Article | PubMed

39. Lacour S, Hammann A, Grazide S, Lagadic-Gossmann D, Athias A, Sergent O, Laurent G, Gambert P, Solary E and Dimanche-Boitrel MT. Cisplatininduced CD95 redistribution into membrane lipid rafts of HT29 human 
Hang et al. Biochemical Compounds 2016,

colon cancer cells. Cancer Res. 2004; 64:3593-8. | Article | PubMed

40. Bruijnincx PC and Sadler PJ. New trends for metal complexes with anticancer activity. Curr Opin Chem Biol. 2008; 12:197-206. | Article | PubMed Abstract | PubMed FullText

41. Sanchez-Cano $C$ and Hannon MJ. Novel and emerging approaches for the delivery of metallo-drugs. Dalton Trans. 2009; 10702-11. | Article | PubMed

42. Dancey JE and Chen HX. Strategies for optimizing combinations of molecularly targeted anticancer agents. Nat Rev Drug Discov. 2006; 5:649-59. | Article | PubMed

43. Galanski M and Keppler BK. Searching for the magic bullet: anticancer platinum drugs which can be accumulated or activated in the tumor tissue. Anticancer Agents Med Chem. 2007; 7:55-73. | Article | PubMed

44. Iyer AK, Khaled G, Fang J and Maeda H. Exploiting the enhanced permeability and retention effect for tumor targeting. Drug Discov Today. 2006; 11:812-8. | Article | PubMed

45. Fang J, Nakamura $\mathrm{H}$ and Maeda $\mathrm{H}$. The EPR effect: Unique features of tumor blood vessels for drug delivery, factors involved, and limitations and augmentation of the effect. Adv Drug Deliv Rev. 2011; 63:136-51. I Article | PubMed

46. Tong, R and J. Cheng: Anticancer polymeric nanomedicines. Journal of Macromolecular Science. Part C: Polymer Reviews. 2007; 47:345-381. | $\underline{\text { Pdf }}$

47. Zhang L, Yu F, Cole AJ, Chertok B, David AE, Wang J and Yang VC. Gum arabic-coated magnetic nanoparticles for potential application in simultaneous magnetic targeting and tumor imaging. AAPS J. 2009; 11:693-9. | Article | PubMed Abstract | PubMed FullText

48. Bangham AD, Standish MM and Watkins JC. Diffusion of univalent ions across the lamellae of swollen phospholipids. J Mol Biol. 1965; 13:23852. | Article | PubMed

49. Liu D, He C, Wang AZ and Lin W. Application of liposomal technologies for delivery of platinum analogs in oncology. Int J Nanomedicine. 2013; 8:3309-19. | Article | PubMed Abstract | PubMed FullText

50. Gabizon A, Catane R, Uziely B, Kaufman B, Safra T, Cohen R, Martin F, Huang $A$ and Barenholz $Y$. Prolonged circulation time and enhanced accumulation in malignant exudates of doxorubicin encapsulated in polyethylene-glycol coated liposomes. Cancer Res. 1994; 54:987-92. | Article | PubMed

51. Stathopoulos GP and Boulikas T. Lipoplatin formulation review article. J Drug Deliv. 2012; 2012:581363. | Article | PubMed Abstract | PubMed FullText

52. Boulikas T. Clinical overview on Lipoplatin: a successful liposomal formulation of cisplatin. Expert Opin Investig Drugs. 2009; 18:1197-218. | Article | PubMed

53. Bharali DJ, Khalil M, Gurbuz M, Simone TM and Mousa SA. Nanoparticles and cancer therapy: a concise review with emphasis on dendrimers. Int J Nanomedicine. 2009; 4:1-7. | Article | PubMed Abstract | PubMed FullText

54. Boulikas T. Low toxicity and anticancer activity of a novel liposomal cisplatin (Lipoplatin) in mouse xenografts. Oncol Rep. 2004; 12:3-12. | Article | PubMed

55. Devarajan P, Tarabishi R, Mishra J, Ma Q, Kourvetaris A, Vougiouka M and Boulikas T. Low renal toxicity of lipoplatin compared to cisplatin in animals. Anticancer Res. 2004; 24:2193-200. | Article | PubMed

56. Marr AK, Kurzman ID and Vail DM. Preclinical evaluation of a liposomeencapsulated formulation of cisplatin in clinically normal dogs. Am J Vet Res. 2004; 65:1474-8. | Article | PubMed

57. Arienti C, Tesei A, Ravaioli A, Ratta M, Carloni S, Mangianti S, Ulivi P, Nicoletti S, Amadori D and Zoli W. Activity of lipoplatin in tumor and in normal cells in vitro. Anticancer Drugs. 2008; 19:983-90. | Article | PubMed

58. Boulikas T, Stathopoulos GP, Volakakis N and Vougiouka M. Systemic Lipoplatin infusion results in preferential tumor uptake in human studies. Anticancer Res. 2005; 25:3031-9. | Article | PubMed

59. Froudarakis ME, Pataka A, Pappas P, Anevlavis S, Argiana E, Nikolaidou M, Kouliatis G, Pozova S, Marselos M and Bouros D. Phase 1 trial of lipoplatin and gemcitabine as a second-line chemotherapy in patients with nonsmall cell lung carcinoma. Cancer. 2008; 113:2752-60. | Article I PubMed

60. Stathopoulos GP, Antoniou D, Dimitroulis J, Stathopoulos J, Marosis K and Michalopoulou P. Comparison of liposomal cisplatin versus cisplatin in non-squamous cell non-small-cell lung cancer. Cancer Chemother Pharmacol. 2011; 68:945-50. | Article | PubMed Abstract | PubMed FullText

61. Veal GJ, Griffin MJ, Price E, Parry A, Dick GS, Little MA, Yule SM, Morland B, Estlin EJ, Hale JP, Pearson AD, Welbank H and Boddy AV. $A$ phase I study in paediatric patients to evaluate the safety and pharmacokinetics of SPI-77, a liposome encapsulated formulation of cisplatin. Br J Cancer. 2001; 84:1029-35. | Article | PubMed Abstract | PubMed FullText

62. Newman MS, Colbern GT, Working PK, Engbers $C$ and Amantea MA. Comparative pharmacokinetics, tissue distribution, and therapeutic effectiveness of cisplatin encapsulated in long-circulating, pegylated liposomes (SPI-077) in tumor-bearing mice. Cancer Chemother Pharmacol. 1999; 43:1-7. I PubMed

63. Bandak S, Goren D, Horowitz A, Tzemach D and Gabizon A. Pharmacological studies of cisplatin encapsulated in long-circulating liposomes in mouse tumor models. Anticancer Drugs. 1999; 10:911-20. | Article | PubMed

64. Zamboni WC, Gervais AC, Egorin MJ, Schellens JH, Zuhowski EG, Pluim D, Joseph E, Hamburger DR, Working PK, Colbern G, Tonda ME, Potter $\mathrm{DM}$ and Eiseman JL. Systemic and tumor disposition of platinum after administration of cisplatin or STEALTH liposomal-cisplatin formulations (SPI-077 and SPI-077 B103) in a preclinical tumor model of melanoma. Cancer Chemother Pharmacol. 2004; 53:329-36. | Article | PubMed

65. Meerum Terwogt JM, Groenewegen G, Pluim D, Maliepaard M, Tibben MM, Huisman A, ten Bokkel Huinink WW, Schot M, Welbank $H$, Voest EE, Beijnen JH and Schellens JM. Phase I and pharmacokinetic study of SPI-77, a liposomal encapsulated dosage form of cisplatin. Cancer Chemother Pharmacol. 2002; 49:201-10. | Article | PubMed

66. Kim ES, Lu C, Khuri FR, Tonda M, Glisson BS, Liu D, Jung M, Hong WK and Herbst RS. A phase II study of STEALTH cisplatin (SPI-77) in patients with advanced non-small cell lung cancer. Lung Cancer. 2001; 34:427-32. | Article I PubMed

67. Seetharamu N, Kim E, Hochster H, Martin F and Muggia F. Phase II study of liposomal cisplatin (SPI-77) in platinum-sensitive recurrences of ovarian cancer. Anticancer Res. 2010; 30:541-5. | Article I PubMed

68. White SC, Lorigan P, Margison GP, Margison JM, Martin F, Thatcher N, Anderson $\mathrm{H}$ and Ranson M. Phase II study of SPI-77 (sterically stabilised liposomal cisplatin) in advanced non-small-cell lung cancer. Br J Cancer. 2006; 95:822-8. | Article | PubMed Abstract | PubMed FullText

69. Kieler-Ferguson HM, Frechet JM and Szoka FC, Jr. Clinical developments of chemotherapeutic nanomedicines: polymers and liposomes for delivery of camptothecins and platinum (II) drugs. Wiley Interdiscip Rev Nanomed Nanobiotechnol. 2013; 5:130-8. | Article | PubMed

70. de Jonge MJ, Slingerland M, Loos WJ, Wiemer EA, Burger H, Mathijssen RH, Kroep JR, den Hollander MA, van der Biessen D, Lam MH, Verweij $\mathrm{J}$ and Gelderblom H. Early cessation of the clinical development of LiPlaCis, a liposomal cisplatin formulation. Eur J Cancer. 2010; 46:301621. | Article | PubMed

71. Tippayamontri T, Kotb R, Paquette B and Sanche L. Cellular uptake and cytoplasm / DNA distribution of cisplatin and oxaliplatin and their liposomal formulation in human colorectal cancer cell HCT116. Invest New Drugs. 2011; 29:1321-7. | Article | PubMed

72. Stathopoulos GP, Boulikas T, Kourvetaris A and Stathopoulos J. Liposomal oxaliplatin in the treatment of advanced cancer: a phase I study. Anticancer Res. 2006; 26:1489-93. | Article | PubMed

73. Lebwohl D and Canetta R. Clinical development of platinum complexes in cancer therapy: an historical perspective and an update. Eur $J$ Cancer. 1998; 34:1522-34. | Article | PubMed

74. Vadiei K, Siddik ZH, Khokhar AR, al-Baker S, Sampedro F and Perez-Soler R. Pharmacokinetics of liposome-entrapped cis-bis-neodecanoatotrans-R,R-1,2-diaminocyclohexane platinum(II) and cisplatin given 
Hang et al. Biochemical Compounds 2016,

i.v. and i.p. in the rat. Cancer Chemother Pharmacol. 1992; 30:365-9. | Article | PubMed

75. Khokhar AR, Wright K, Siddik ZH and Perez-Soler R. Organ distribution and tumor uptake of liposome entrapped cis-bis-neodecanoato trans- $R$, $\mathrm{R}-1,2$ diaminocyclohexane platinum (II) administered intravenously and into the proper hepatic artery. Cancer Chemother Pharmacol. 1988; 22:223-7. | Article | PubMed

76. Perez-Soler R, Yang LY, Drewinko B, Lauterzstain J and Khokhar $A R$. Increased cytotoxicity and reversal of resistance to cisdiamminedichloro-platinum(II) with entrapment of cis-Bisneodecanoato-trans-R,R-1,2-diaminocyclohexaneplatinum (II) in multilamellar lipid vesicles. Cancer Res. 1988; 48:4509-12. | Article | PubMed

77. Perez-Soler R, Khokhar AR and Lopez-Berestein G. Treatment and prophylaxis of experimental liver metastases of M5076 reticulosarcoma with cis-bis-neodecanoato-trans-R,R-1,2-diaminocyclohexaneplatinum (II) encapsulated in multilamellar vesicles. Cancer Res. 1987; 47:6462-6. | Article | PubMed

78. Perez-Soler R, Lopez-Berestein G, Lautersztain J, al-Baker S, Francis K, Macias-Kiger D, Raber MN and Khokhar AR. Phase I clinical and pharmacological study of liposome-entrapped cis-bis-neodecanoatotrans-R,R-1,2-diaminocyclohexane platinum(II). Cancer Res. 1990; 50:4254-9. | Article | PubMed

79. Dragovich T, Mendelson D, Kurtin S, Richardson K, Von Hoff D and Hoos A. A Phase 2 trial of the liposomal DACH platinum L-NDDP in patients with therapy-refractory advanced colorectal cancer. Cancer Chemother Pharmacol. 2006; 58:759-64. | Article | PubMed

80. Suzuki R, Takizawa T, Kuwata Y, Mutoh M, Ishiguro N, Utoguchi N, Shinohara A, Eriguchi $M$, Yanagie $H$ and Maruyama K. Effective antitumor activity of oxaliplatin encapsulated in transferrin-PEG-liposome. Int J Pharm. 2008; 346:143-50. | Article | PubMed

81. Sankhala K, A. Mita, R. Adinin, L. Wood, M. Beeram, S. Bullock, N. Yamagata, K. Matsuno, T. Fujisawa and A. Phan. A phase I pharmacokinetic (PK) study of MBP-426, a novel liposome encapsulated oxaliplatin. J Clin Oncol. 2009. 27:2535. | Pdf

82. Senzer N.N., K. Matsuno, N. Yamagata, T. Fujisawa, E. Wasserman, W. Sutherland, S. Sharma and A. Phan. Abstract C36: MBP-426, a novel liposome-encapsulated oxaliplatin, in combination with 5-FU/ leucovorin (LV): Phase I results of a Phase I/II study in gastroesophageal adenocarcinoma, with pharmacokinetics. Molecular Cancer Therapeutics. 2009; 8:C36-C36. I Article

83. Croy SR and Kwon GS. Polymeric micelles for drug delivery. Curr Pharm Des. 2006; 12:4669-84. | Article | PubMed

84. Gong J, Chen $\mathrm{M}$, Zheng $\mathrm{Y}$, Wang $\mathrm{S}$ and Wang Y. Polymeric micelles drug delivery system in oncology. J Control Release. 2012; 159:312-23. I Article | PubMed

85. Nishiyama N, Okazaki S, Cabral H, Miyamoto M, Kato Y, Sugiyama Y, Nishio K, Matsumura Y and Kataoka K. Novel cisplatin-incorporated polymeric micelles can eradicate solid tumors in mice. Cancer Res. 2003. 63:8977-83. | Article | PubMed

86. Uchino $\mathrm{H}$, Matsumura $\mathrm{Y}$, Negishi T, Koizumi F, Hayashi T, Honda T, Nishiyama N, Kataoka K, Naito S and Kakizoe T. Cisplatin-incorporating polymeric micelles (NC-6004) can reduce nephrotoxicity and neurotoxicity of cisplatin in rats. Br J Cancer. 2005; 93:678-87. | Article | PubMed Abstract | PubMed FullText

87. Matsumura $Y$ and Kataoka K. Preclinical and clinical studies of anticancer agent-incorporating polymer micelles. Cancer Sci. 2009; 100:572-9. | Article | PubMed

88. Wilson R, R. Plummer, J. Adam, M. Eatock, A. Boddy, M. Griffin, R. Miller, Y. Matsumura, T. Shimizu and H. Calvert. Phase I and pharmacokinetic study of NC-6004, a new platinum entity of cisplatin-conjugated polymer forming micelles. ASCO Annual Meeting Proceedings. 2008.

89. Company. I Website

90. Cabral H, Nishiyama N, Okazaki S, Koyama H and Kataoka K. Preparation and biological properties of dichloro(1,2-diaminocyclohexane) platinum(II) (DACHPt)-loaded polymeric micelles. J Control Release. 2005; 101:223-32. | Article | PubMed
91. Rafi M, Cabral H, Kano MR, Mi P, Iwata C, Yashiro M, Hirakawa $\mathrm{K}$, Miyazono K, Nishiyama $\mathrm{N}$ and Kataoka K. Polymeric micelles incorporating (1,2-diaminocyclohexane)platinum (II) suppress the growth of orthotopic scirrhous gastric tumors and their lymph node metastasis. J Control Release. 2012; 159:189-96. | Article | PubMed

92. Ueno T, Endo K, Hori K, Ozaki N, Tsuji A, Kondo S, Wakisaka N, Murono S, Kataoka K, Kato $\mathrm{Y}$ and Yoshizaki T. Assessment of antitumor activity and acute peripheral neuropathy of 1,2-diaminocyclohexane platinum (II)incorporating micelles (NC-4016). Int J Nanomedicine. 2014; 9:3005-12. | Article | PubMed Abstract | PubMed FullText

\section{Citation:}

Hang Z, Cooper MA and Ziora ZM. Platinum-based anticancer drugs encapsulated liposome and polymeric micelle formulation in clinical trials. Bio Chem Comp. 2016; 4:1.

http://dx.doi.org/10.7243/2052-9341-4-2 